Check for updates

Cite this: J. Mater. Chem. B, 2019, 7, 1974

Received 17th October 2018, Accepted 11th February 2019

DOI: $10.1039 / c 8 t b 02738 b$

rsc.li/materials-b

\title{
Bibliographic review on the state of the art of strontium and zinc based regenerative therapies. Recent developments and clinical applications $\dagger$
}

\author{
Mirta Jiménez, ${ }^{a}$ Cristina Abradelo, ${ }^{a}$ Julio San Román ${ }^{b c}$ and Luis Rojo (D) *bc
}

\begin{abstract}
Musculoskeletal disorders such as osteoporosis and rheumatoid arthritis are responsible for more than 25k deaths every year in the European Union and constitute a chronic burden on the individuals who suffer from this condition. There is no medical cure for these diseases and there are many therapies applied which have limited effectiveness and severe side effects over time. Regenerative therapies are being studied as a potential treatment for musculoskeletal diseases and are known for their upgrading effects of the natural healing processes carried out in the human body. It is believed that both strontium and zinc play an essential role in bone and cartilage tissue formation, which has led many scientists to study the effect of including these elements to promote tissue formation and inhibit its resorption. In this review, a deep analysis is undertaken of the most relevant developments in strontium and zinc based regenerative therapies that have occurred in the last five years, taking into consideration only those studies reporting significant progress towards real clinical applications. This review brings up to date the state of the art of strontium and zinc based regenerative therapies as it is believed that both have a promoting effect on tissue formation and have an essential role inhibiting resorption in musculoskeletal disorders.
\end{abstract}

\section{Introduction}

Bone and cartilage health and repair consist of maintaining the balance between tissue resorption and formation. Various musculoskeletal diseases such as Paget's disease, osteoarthritis, rheumatoid arthritis, osteogenesis imperfecta and osteoporosis derive from an imbalance of these processes. ${ }^{1,2}$ This group of diseases constitutes a major burden on individuals and health systems being responsible for more than $25 \mathrm{k}$ deaths every year in the European Union, ${ }^{3}$ where $66 \%$ were women. ${ }^{4}$ This situation encourages European research priorities to improve advanced therapies able to regenerate and restore tissues, organs and functions. ${ }^{5}$ Tissue loss, particularly of bone and cartilage, continues to be a challenge; ${ }^{6}$ recent statistics reveal that one in three women and one in five men will have an osteoporotic fracture over the age of fifty. ${ }^{7}$ When bone tissue loss is present,

\footnotetext{
${ }^{a}$ Unversidad CEU San Pablo, Spain

${ }^{b}$ Instituto de Ciencia y tecnología de Polímeros, CSIC, Spain. E-mail: rojodelolmo@ictp.csic.es

${ }^{c}$ Consorcio Centro de Investigación Biomédica en Red de Bioingeniería,

Biomateriales y Nanomedicina Spain, Spain

$\dagger$ Electronic supplementary information (ESI) available: Fig. S1. Flow diagram showing the screening process carried out in this review. See DOI: 10.1039/ c8tb02738b
}

fracture treatment carries important challenges due to the high risk of mortality in the first year. ${ }^{8}$

The most common form of musculoskeletal disorders is osteoporosis, also known as "primary osteoporosis", which is the result of bone loss due to bone resorption, which consists mainly of the differentiation of a stromal cell/osteoblast or a macrophage into an osteoclast, ${ }^{9}$ and deterioration of bone structure as people age. ${ }^{10}$ It is believed that osteoclastic bone resorption is regulated by the RANKL/osteoprotegerin (OPG)/ RANK pathway, while osteoblastic bone formation is controlled by the canonical Wnt/ $\beta$-catenin signalling pathway. ${ }^{11-13}$ There are multiple risk factors for osteoporosis including sex, obesity, genetic predisposition, inflammation, stress and lifestyle. ${ }^{14}$ The current therapies used for osteoporosis include: vitamin D and calcium supplements, bisphosphonates, teriparatide (TPH), hormone replacement therapy, selective oestrogen receptor modulators (SERMs), RANK ligand inhibitors and strontium ranelate, in which the safety issues and side effects are quite concerning. ${ }^{15}$

Regenerative therapies imply the replacement or regeneration of human cells, tissues or organs with the purpose of returning the patient to full health, ${ }^{16}$ by using concrete factors to upgrade the natural healing potential. ${ }^{17}$ Currently there are still many diseases with no effective medical therapy which could be treated with tissue replacement. ${ }^{18}$ Several strategies 
can be used: cell-based therapy, implantation of scaffolds seeded with cells and biomaterials which can be enriched with bioactive factors. ${ }^{19}$

Strontium ( $\mathrm{Sr}$ ) is an alkaline earth element with close similarities with calcium $(\mathrm{Ca})$ due to its bone-seeking properties. It has been found that vitamin $\mathrm{D}$ induces $\mathrm{Sr}$ absorption while $\mathrm{Ca}$ inhibits it. ${ }^{20} \mathrm{Sr}$ plays important physicochemical and biological roles in the application of bone repair materials; ${ }^{21}$ it is known to be involved in the human bone mineral metabolism by inducing the expression of osteogenic-related genes, ${ }^{22}$ differentiation markers, and proliferation and reducing apoptosis levels. ${ }^{23}$ Moreover, Pasqualetti S. et al. have demonstrated that $\mathrm{Sr}$ also affects bone mineralization during skeletal development in zebrafish embryos. ${ }^{24}$ For instance, strontium ranelate (SR) is currently used as a treatment against bone fractures in postmenopausal women. ${ }^{25}$ Although slight toxicity in some of the patients was reported, ${ }^{26}$ the latest studies report a low dose of Sr promotes osteogenesis, but high doses can, in explicit cases, induce apoptosis. ${ }^{27}$ Additionally, Sr enriched biomaterials have been shown to induce osteogenesis and new bone formation (Fig. 1). ${ }^{28}$

On the other hand, it is established that zinc $(\mathrm{Zn})$ is an essential cofactor for enzymes involved in DNA, RNA and protein synthesis such as bone matrix components and is an essential component of the cell membrane repair machinery and musculoskeletal matrix regeneration. ${ }^{29}$ The role of $\mathrm{Zn}$ in bone is twofold: firstly, Zn plays a structural role in the bone matrix and on the other hand, it is involved in the preservation of bone mass by stimulating bone formation by osteoblasts and inhibition of bone resorption by osteoclasts (Fig. 1). ${ }^{30}$ Furthermore, it has been confirmed that $\mathrm{Zn}$ deficiency leads to growth and gonadal development retardation, either for a deficient $\mathrm{Zn}$ intake or a defect in absorption. ${ }^{31,32}$ Not only does $\mathrm{Zn}$ act as an inhibitor of bone tissue loss but also plays an important role in cartilage II and SOX9 gene expression, cartilage matrix metabolism and inflammatory-related diseases carried out by Zn-dependent matrix metalloproteinases (MMPs). ${ }^{33-36}$

Since these two cations are easily available from accessible resources and they do not suffer degradation reactions during processing, storage and transport, there is an important research activity developing promising alternatives to more unstable, and sometimes prohibitive, growth factor and signalling biomacromolecule based therapies for real clinical applications. Thus, the aims of this review are to provide an expanded analysis of the scientific literature focused on the application of $\mathrm{Sr}$ and $\mathrm{Zn}$ as bioactive agents in musculoskeletal regenerative therapies in the last five years, and to deliver a valuable guide for a wide range of researchers in the fields of medicine, chemistry and material and pharmaceutical sciences interested in the biological role and significance of $\mathrm{Sr}$ and $\mathrm{Zn}$ containing materials in regenerative medicine.

\section{Tissue engineering based on $\mathrm{Zn}$ and Sr containing scaffolds}

Scaffolds have multiple applications and play an essential role in tissue engineering and can be obtained from a wide variety

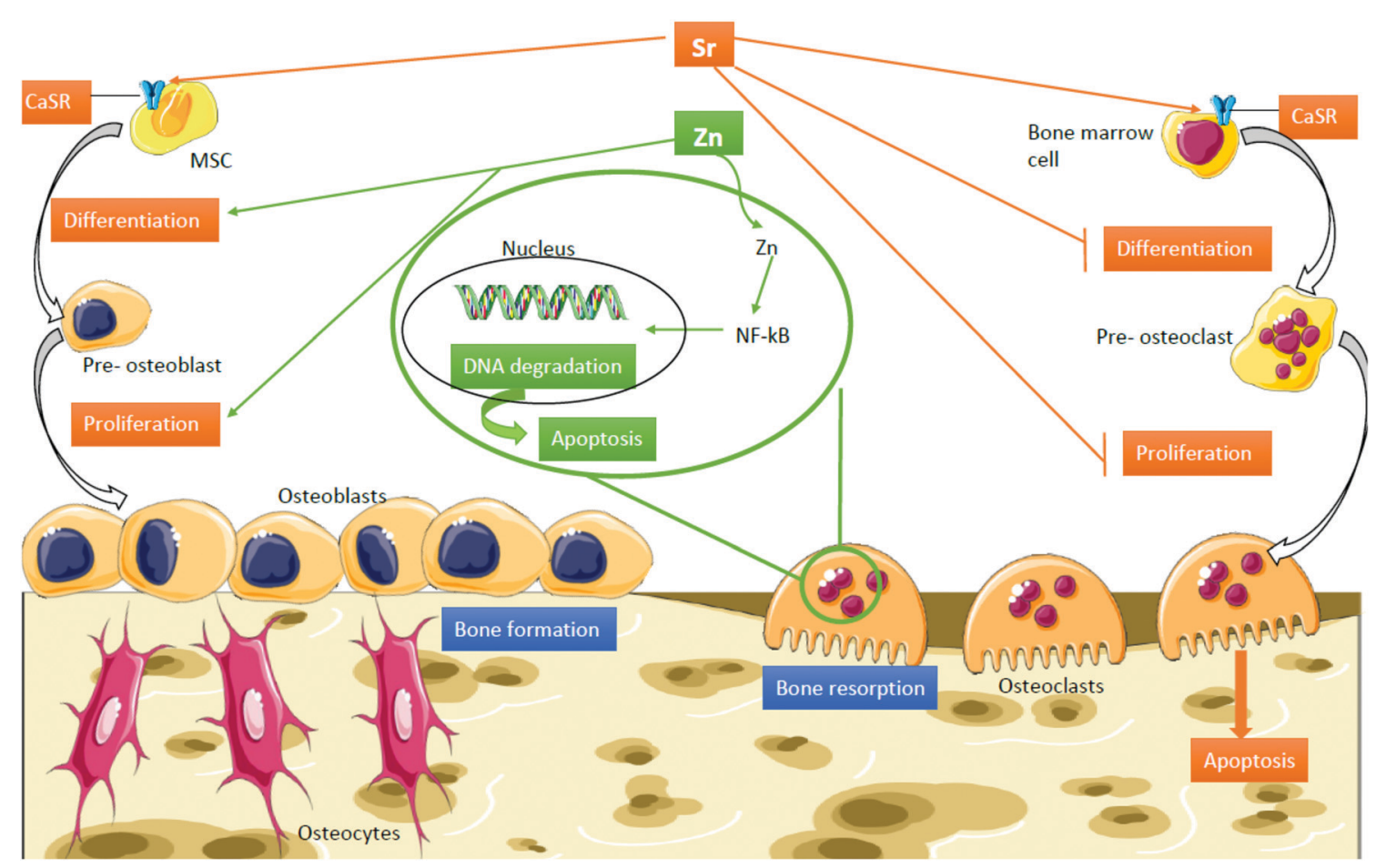

Fig. 1 Mechanisms of action of Sr and Zn in bone. Abbreviations: CaSR, calcium sensing receptor; MSC, mesenchymal stem cell; NF-kb, nuclear factor kappa-light-chain-enhancer of activated B cells. 
of fabrication procedures such as 3D printing, electrospinning, cryo-photo-redox-mediated polymerization or sintering. These scaffolds can be made from natural existing polymers, synthetic materials or combinations of both, in order to mimic the physicochemical and biological properties of the damaged or missing tissue by creation of an environment that promotes the capacity of cells to integrate, proliferate and differentiate. ${ }^{37-39}$

A bioactive glass is a biocompatible material that can mimic human bone and induce re-growth. It also can be mixed with other materials such as $\mathrm{Sr}$ to promote its bioactivity. ${ }^{40}$ Nine authors were found to be operating with this biomaterial, though applying different combinations and performing experiments on different cell lines and/or animals: a Sr substituted bioactive glass, where calcium oxide $(\mathrm{CaO})$ was substituted by $\mathrm{Sr}$ in three different molar proportions, being $0 \%, 50 \%$ and $100 \%$, using bone marrow stromal cells (BMSCs); ${ }^{41}$ a sol-gel synthesized partially substituted $\mathrm{CaO}$ by $\mathrm{SrO}$ (on a $0-10 \%$ molar basis) bioactive glass on clonal osteoblast-like mouse calvarial cells (MC3T3-E1); ${ }^{42}$ a $\mathrm{Sr}$ and lithium (Li) co-doped bioactive glass scaffold using all inorganic components $\left(\mathrm{SrCO}_{3}\right.$ and $\left.\mathrm{Li}_{2} \mathrm{CO}_{3}\right)$ on mouse embryonic fibroblast cells (NIH3T3) and further along expanding the experiment to New Zealand white rabbits; ${ }^{43}$ a $\mathrm{Sr}$ containing calcium sulphate (CS)/poly (amino acid) bioactive graft, where $\mathrm{Sr}$ and $\mathrm{CS}$ were directly added into the scaffold mix performed on MC3T3-E1 cells and as well as on New Zealand white rabbits; ${ }^{44}$ a porous $\mathrm{Sr}$ incorporating mesopore-bioglass (Sr-MBG) scaffold, in comparison to a non-doped mesopore bioglass (MBG) where 15 female Wistar rats were randomly assigned into three groups: (1) control unfilled periodontal defects, (2) MBG alone and (3) Sr-MBG scaffolds; ${ }^{45} \mathrm{Sr}$ doped bioactive phosphate glasses of general composition $40\left(\mathrm{P}_{2} \mathrm{O}_{5}\right)$ $25(\mathrm{CaO})-5\left(\mathrm{Na}_{2} \mathrm{O}\right)-(30-x) \mathrm{MgO}-x(\mathrm{SrO})$ with $x=0,1,5$, and 10 where $\mathrm{Sr}$ was substituted in magnesium's $(\mathrm{Mg})$ place were analysed using human mesenchymal stem cells (hMSCs); ${ }^{46} \mathrm{Sr}$ and Ca releasing titanium-stabilised phosphate-based glasses of general formula $25\left(\mathrm{P}_{2} \mathrm{O}_{5}\right)-5\left(\mathrm{Na}_{2} \mathrm{O}\right)-5\left(\mathrm{TiO}_{2}\right)-(35-x)$ CaO $-x(\mathrm{SrO})$ where $x=0,3.5,17.5$, and 35 and $\mathrm{Sr}$ was substituting $\mathrm{Ca}$ in the human osteosarcoma cell line (MG-63); ${ }^{47}$ Human Umbilical Vein Endothelial Cells (HUVECs) were treated with a phosphate based but also multicomponent bioactive glass: $\mathrm{SiO}_{2}-\mathrm{P}_{2} \mathrm{O}_{5}-\mathrm{CaO}-$ $\mathrm{SrO}-\mathrm{Na}_{2} \mathrm{O}-\mathrm{MgO}-\mathrm{ZnO}-\mathrm{K}_{2} \mathrm{O}$, where four groups were assembled, Ca-glass, Sr-glass, Ca-cobalt (Co)-glass and Sr-Co-glass; ${ }^{48}$ and lastly, phosphate based glasses that contain $\mathrm{Sr}, \mathrm{Zn}$ and $\mathrm{Ca}$ of general formula $\left(\mathrm{P}_{2} \mathrm{O}_{5}\right)-\left(\mathrm{Na}_{2} \mathrm{O}\right)-\left(\mathrm{TiO}_{2}\right)-(\mathrm{CaO})-(\mathrm{SrO})$ or $(\mathrm{ZnO})$ on MG-63 cells. ${ }^{49}$ The last four fabricated the bioactive glasses via the melt-quenching technique, which consists of a quenching consecutive to the fusion of two or more oxide components. ${ }^{50}$

It is well known that the bone extracellular matrix (ECM) is composed of inorganic components such as hydroxyapatite crystals and organic components such as collagen, ${ }^{51}$ which arrange into nanofibers controlling the behaviour of the cells. Hence, using nanofibers as a biomaterial is a wise decision as it mimics the situation in vivo. ${ }^{52}$ Weng L. et al. chose to fuse the utility of bioactive glasses and nanofibers, using glass material to fabricate nanofibers substituting $\mathrm{Ca}$ for $\mathrm{Sr}$ and copper $(\mathrm{Cu})$, creating several scaffolds: undoped or Ca bioactive glass fibres;
$50 \% \mathrm{Sr}$ doped bioactive glass fibers; $1 \% \mathrm{Cu}$ and $50 \% \mathrm{Sr}$ doped bioactive glass fibers; and $0.5 \% \mathrm{Cu}$ and $50 \% \mathrm{Sr}$ doped bioactive glass nanofibers in adipose tissue-derived mesenchymal stem cells (ADSCs). ${ }^{53}$ Other Sr doped nanofibers were analysed: poly( $\varepsilon$-caprolactone) (PCL) based nanofibers. ${ }^{54,55}$ In the first case ${ }^{54}$ hMSCs were treated with $\mathrm{SrCrO}_{3}$-electrospun nanofibers where several samples were made: PCL $\left(\mathrm{SrCO}_{3} 0 \%\right), \mathrm{PCL} / \mathrm{SrC10}$ $\left(\mathrm{SrCO}_{3} 10 \%\right)$ and $\mathrm{PCL} / \mathrm{SrC} 20\left(\mathrm{SrCO}_{3} 20 \%\right)$. On the other hand, ${ }^{55}$ strontium phosphate $\left[\mathrm{Sr}_{3}\left(\mathrm{PO}_{4}\right)_{2}\right]$ was added by immersing the nanofibers in a strontium phosphate solution, obtaining three samples: Sr coated PCL nanofibers, PCL $+0.8 \%$ Sr nanofibers and PCL-only nanofibers as the control, and they were used to treat stem cells from human exfoliated deciduous teeth (SHEDs).

As already stated, the bone ECM is composed of inorganic components such as hydroxyapatite crystals, so creating a biomaterial using hydroxyapatite and implanting it into an animal gives the advantage of not having any kind of adverse reactions in addition to perfect fitting. Two combinations of hydroxyapatite materials were found: Sr containing nanostructured hydroxyapatite microspheres (SrHA) compared to stoichiometric hydroxyapatite (HA) microspheres were implanted into a sheep, ${ }^{56}$ and $\mathrm{Sr}$ substituted hydroxyapatite (Sr-HA) was obtained by adding $\mathrm{Sr}^{2+}$ ions into a $\mathrm{Ca}^{2+}$ solution; the appropriate amounts of $\mathrm{Sr}\left(\mathrm{NO}_{3}\right)_{2}$ and $\mathrm{Ca}\left(\mathrm{NO}_{3}\right)_{2} \cdot 4 \mathrm{H}_{2} \mathrm{O}$ were dissolved in order to obtain $8 \%$ or $50 \%$ (molar ratio) of $\mathrm{Ca}^{2+}$ substituted by $\mathrm{Sr}^{2+}$ (8Sr-HA and 50Sr-HA) and further along implanted into mice. ${ }^{57}$

Bone cements are usually composed of two systems: powder (homopolymer PMMA (polymethyl methacrylate) + BPO (benzoyl peroxide) $/ \mathrm{ZrO}_{2}$ (zirconia) $/ \mathrm{BaSO}_{4}$ (barium sulphate)); and liquid (monomer MMA + hydroquinone $+\mathrm{N}, \mathrm{N}$-dimethyl para-toluidine (DMPT)). ${ }^{58}$ Cui X. et al. ${ }^{59}$ offered an innovative proposal by fusing these two concepts: bone cements and bioactive glasses, integrating a Sr containing borate bioactive glass ( $\mathrm{SrBG}$ ) into a bone cement in several concentrations: $10 \mathrm{SrBG}, 20 \mathrm{SrBG}$ and $30 \mathrm{SrBG}$ being $0.2,0.4$ and $0.6 \mathrm{~g}$ of SrBG respectively and comparing the results with a non-doped PMMA cement. This experiment was carried out on the MC3T3-E1 cell line as well as in vivo, in healthy and osteoporotic Sprague-Dawley rats. On the other hand, a Sr loaded bone cement (Sr-BC) was prepared in different concentrations $\mathrm{Sr} /(\mathrm{Ca}+\mathrm{Sr})=0 \%, 2 \%, 5 \%$ in a different study where the experiment was only carried out in vitro on the mouse monocyte cell line (RAW 264.7) and the MC3T3-E1 cell line. ${ }^{60}$ Further, a cement precursor was found composed of $58 \mathrm{wt} \% \alpha$-tricalcium phosphate, 24 wt $\%$ calcium hydrogen phosphate, $8.5 \mathrm{wt} \%$ hydroxyapatite and $8.5 \mathrm{wt} \%$ strontium carbonate and later mixed with a $4 \%$ aqueous disodium hydrogen phosphate solution to assist new bone formation in Sprague-Dawley rats, ${ }^{61}$ and silicon (Si) and $\mathrm{Zn}$ doped brushite cements (BrCs) alone and in combination with insulin like growth factor 1 (IGF-1), coming to four different scaffolds: (IGF-1) BrC, (IGF-1) Si-BrC, (IGF-1) Zn-BrC, and (IGF-1) Si/Zn-BrC cements, on New Zealand white rabbits. ${ }^{62}$

Moreover, scaffolds from very different compositions were found: SrO doped biosilicate scaffolds, fabricated by mixing $\mathrm{Mg}_{2} \mathrm{SiO}_{4}$ and $\mathrm{CaSiO}_{3}$ and adding SrO in different ratios, being 0SrO (0 wt $\%), 0.5 \mathrm{SrO}$ (0.5 wt $\%), 1 \mathrm{SrO}$ ( $1 \mathrm{wt} \%)$, 2SrO (2 wt $\%$ ), and $3 \mathrm{SrO}(3 \mathrm{wt} \%)$, were used to treat MG-63 cells; ${ }^{63}$ a zinc 
silicate mineral coated PLLA scaffold compared to a non-coated scaffold and tissue culture plastic (TCPS), cultured with adipocyte derived stem cells (ADSCs); ${ }^{64}$ a strontium chloride $\left(\mathrm{SrCl}_{2}\right)$ coated porcine femur cancellous bone derived scaffold (CPB) subsequently coated with polycaprolactone (PCL) obtaining $\mathrm{CPB} / \mathrm{Sr}$ / PCL on hMSCs; ${ }^{65}$ a sol-gel method synthesized hybrid scaffold incorporating: phosphate ions, calcium from calcium dichloride $\left(\mathrm{CaCl}_{2} \cdot 2 \mathrm{H}_{2} \mathrm{O}\right)$ and $\mathrm{Sr}$ from strontium dichloride hexahydrate $\left(\mathrm{SrCl}_{2} \cdot 6 \mathrm{H}_{2} \mathrm{O}\right)$ was incorporated into human osteoblast cell line (HOB) cultures; ${ }^{66}$ a $\mathrm{Sr}$ folate (SrFO) loaded bio-hybrid porous scaffold obtained by interpenetrating beta tricalcium phosphate ( $\beta$ TCP) and polyethylene glycol dimethacrylate networks in contrast with a $\beta$ TCP scaffold, which was used in an experiment in human dental pulp stem cells (HDPSCs) as well as in vivo in Wistar rats; ${ }^{67}$ Wharton's jelly-derived mesenchymal stem cells (WJCs) were treated with either a rod-like nano hydroxyapatite (RN-HA) or a flake-like micro hydroxyapatite (FM-HA) as a coating for a $\mathrm{Mg}-\mathrm{Zn}-\mathrm{Ca}$ alloy scaffold in another study; ${ }^{68}$ a Collagen type-I (Col-I) coated magnesium-zirconia (Mg-Zr) alloy, containing different quantities of $\mathrm{Sr}$, where the scaffolds were divided into 3 samples: No-Sr, Low-Sr (1.82 wt $\%$ ) and High-Sr (4.8 wt\%) and later implanted into New Zealand white rabbits; ${ }^{69}$ another $\mathrm{Sr}$ containing HA/polylactide composite group with four scaffolds was obtained: CT (control, Sr0/polylactide), SrL (Sr0.5/polylactide), SrM (Sr5/polylactide) and $\mathrm{SrH}$ (Sr50/polylactide), which were as well implanted into New Zealand white rabbits; ${ }^{70}$ and lastly, three different studies chose to use a calcium silicate based bio-ceramic that contains $\mathrm{Sr}$ and $\mathrm{Zn}$ ions: strontium-hardystonite-gahnite (Sr-HT-gahnite) scaffolds, ${ }^{71-73}$ since it has been recently studied due to its biocompatibility and exclusive microstructure (Fig. 2). The structure consists of crystalline strontium-hardystonite grains embedded with submicron gahnite crystals (prevents cracks). ${ }^{74}$
The studies respectively carried out the experiments on human peripheral blood monocytes (hPBM), ${ }^{71}$ adult stem cells (ASCs) and HUVEC cell lines ${ }^{72}$ and, lastly, primary human osteoblasts (HOBs) and New Zealand white rabbits. ${ }^{73}$

\section{Osteoinductive titanium surfaces containing $\mathrm{Sr}$}

Titanium (Ti) and its alloys have been used in a wide range of clinical applications such as orthopaedic and dental implants. Biocompatibility is the most significant property to be accomplished by a biomaterial to be used in any clinical application. We know that $\mathrm{Ti}$ is a chemically and mechanically stable, non-toxic, bone integrating material, ${ }^{75}$ which however does not fulfil rapid osseointegration regenerative clinical use demands. ${ }^{76}$ Different surface modifications have been recently described for inclusion of osteogenic elements. ${ }^{77}$ On this subject, eight articles discussed the possibilities of doping titanium surfaces with $\mathrm{Sr}$, well known for its possibilities to intensify bone regenerating features, such as $\mathrm{SrTiO}_{3} / \mathrm{TiO}_{2}{ }^{76}$ and $\mathrm{Sr}$ loaded titania nanotubes, ${ }^{78}$ consisting of adding the Sr through a hydrothermal treatment. ${ }^{79,80}$ In both cases, the RAW 264.7 cell line was used for the experiment in vitro, although $\mathrm{B}$. Mi et al. expanded their experiment in vivo, performing it on Sprague-Dawley rats (Fig. 3). ${ }^{78}$

Furthermore, the immune response to implanted biomaterials is imperative to apprehend whether a material is suitable or not. Knowing that $\mathrm{Sr}$ and $\mathrm{Ca}$ can induce osteogenesis and abolish inflammation, two papers were found which take advantage of these promising properties: BMSCs and RAW 264.7 cell lines were used in an experiment consisting of $\mathrm{Sr}$ and $\mathrm{Ca}$ co-doped titanium oxides, where numerous concentration ratios were used to go
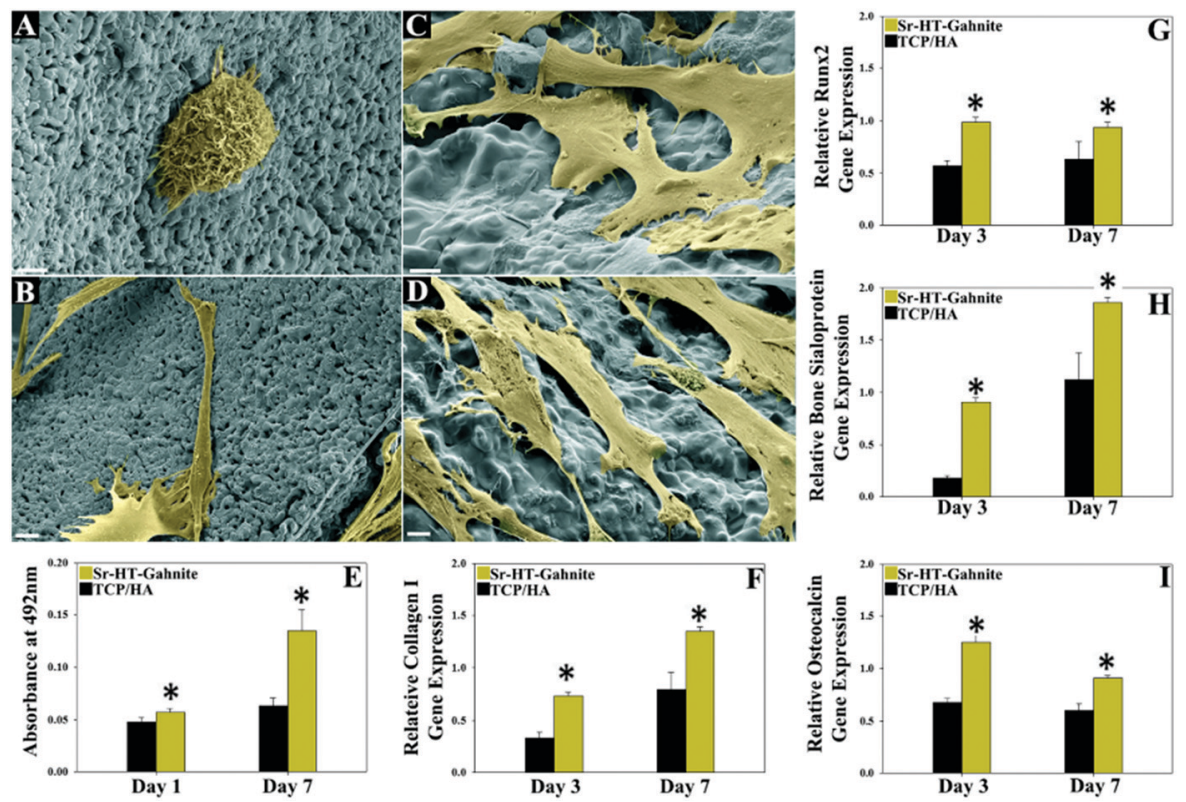

Fig. 2 Interaction of primary human bone cells (HOBs) with the scaffolds. The effects of Sr-HT-gahnite and TCP/HA scaffolds on: (A-D) attachment and spreading, (E) proliferation and (F-I) osteogenic gene expression of HOBs. Reproduced from J. Biomater. 2018, 5, 40-45 with permission from (C) Elsevier. 


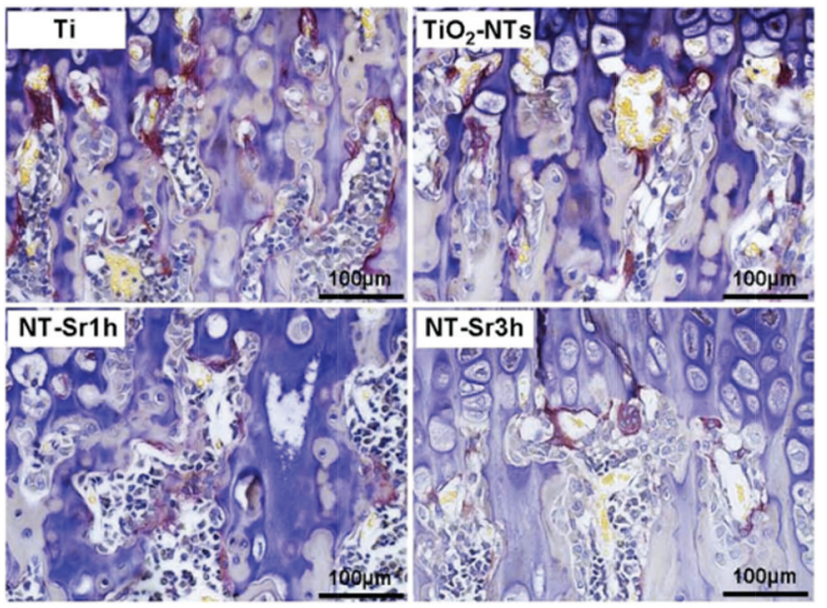

Fig. 3 NT-Sr decreases osteoclast formation and function in vivo as demonstrated from TRAP staining on the metaphyseal regions of the proximal tibias of Sprague-Dawley rats. Reproduced under a Creative Commons Attribution 4.0 International License, from Sci. Rep. 7, 2328 (2017) with permission from Nature Publishing Group ${ }^{\circledR}$

through the experiment: Ti, Ti-Ca10, Ti-Sr10, Ti-Ca10Sr10, Ti-Ca10Sr5 and Ti-Ca10Sr2.5, obtained by an electrochemical treatment of calcium chloride and strontium dichloride solutions on titanium plates ${ }^{79}$ and $\mathrm{Sr}$ doped calcium (Ca)- and phosphate (P)-containing titanium oxide layers. The Ti oxide layers were modified by the micro-arc oxidation method (MAO), which is known for augmenting biocompatibility and osseointegration in vivo ${ }^{81}$ these $\mathrm{Sr}$ doped calcium (Ca)- and phosphate(P)containing titanium oxide layers were also used further along for an experiment in vivo on $\mathrm{C} 57 \mathrm{BL} / 6$ mice. In another study, electrolytes with different proportions of Sr: Sr-0M, Sr-0.05M, Sr-0.1M and Sr-0.15M were analysed using MC3T3E1 cells. ${ }^{80}$ Calcium phosphate (CPS) coated titanium sheets, adding $\mathrm{Sr}^{2+}$ by vertical immersion to reach varying concentrations of $\mathrm{Sr}^{2+}$ in CPS $(0,10$, and $1000 \mu \mathrm{M})$, were tested on hMSCs looking for osteogenic differentiation; ${ }^{82}$ a SrO layer on a sandblasted large grit double acid etched (SLA) surface produced by hydrothermal treatment using a Sr containing solution was implanted into New Zealand white rabbits; ${ }^{83}$ and lastly, titanium implants were induced to release $\mathrm{Sr}(\mathrm{Sr}-\mathrm{Ti})$ or $\mathrm{Mg}(\mathrm{Mg}-\mathrm{Ti})$ ions in Japanese white rabbits. $^{84}$

Sodium alginate (SA) is a promising and efficient biomaterial for bone formation and healing, ${ }^{85,86}$ and its utility in bone tissue regeneration has been studied as a coating with $\mathrm{Sr}$ and dopamine (DOPA) on a titanium (Ti) surface, which are well-known for their potential characteristics for bone tissue engineering; five samples were made: Ti, Ti/DOPA, Ti/DOPA/SA, Ti/DOPA/SA/Sr1 (1 wt\% Sr) and Ti/DOPA/SA/Sr5 (5 wt $\%$ Sr) and tested using MG-63 cells. ${ }^{87}$

\section{Strontium ranelate based therapies}

Strontium ranelate (SR) is composed of two atoms of stable Sr combined with organic ranelic acid. It seems to have unique effects of inhibiting bone resorption as well as stimulating bone formation and it currently used as a treatment for osteoporosis and other bone diseases. ${ }^{88}$ Since it has outstanding properties for bone tissue engineering, various authors decided to evaluate the effects of this compound (Fig. 4): a SR therapy was investigated to assess its effects on fracture frequency and bone mass and strength in mice; ${ }^{89}$ a SR treatment was examined in a postmenopausal woman with osteonecrosis of the jaw after long-term oral bisphosphonate administration; ${ }^{90}$ SR in the repair of standardized intrabuccal bone defects in Lewis rats was evaluated; ${ }^{91}$ the effects of insulin and SR on guided bone regeneration in diabetic Wistar rats were analysed; ${ }^{92}$ how a previous biophosphonate treatment can modify the effects of SR on bone mineral density was investigated in humans; ${ }^{93}$ the properties of SR for the stimulation of trabecular bone formation in a Sprague-Dawley rat tibial bone defect healing process; ${ }^{94}$ the effects of SR on spinal interbody fusion surgery in an osteoporotic Sprague-Dawley rat; ${ }^{95}$ and finally, how SR causes osteophyte overgrowth in a model of early phase osteoarthritis in Dunkin Hartley albino guinea pigs. ${ }^{96}$

\section{Vehicles for zinc and strontium delivery}

Microparticles (MPs) have been recently investigated for cartilage and bone regeneration using different materials; they also have the capacity to act as cell carriers by seeding the microparticles with cells before implantation. ${ }^{97}$ For this matter, $\mathrm{Sr} / \mathrm{Zn}$ doped microspheres were evaluated using $\mathrm{Zn}$ doped mesoporous hydroxyapatite microspheres (MHMs) to construct a novel biomimetic scaffold with the purposes of bone regeneration in BMSCs (Fig. 5). Four scaffolds named: collagen (Coll) scaffold, MHM/Coll scaffold, Zn2-MHM/Coll scaffold, and Zn5-MHM/Coll were prepared and tested on an in vivo rat model. ${ }^{98}$ Analogously, strontium polyphosphate microparticles (Sr-a-polyP-MP) were analysed to induce mineralization of bone cells in comparison
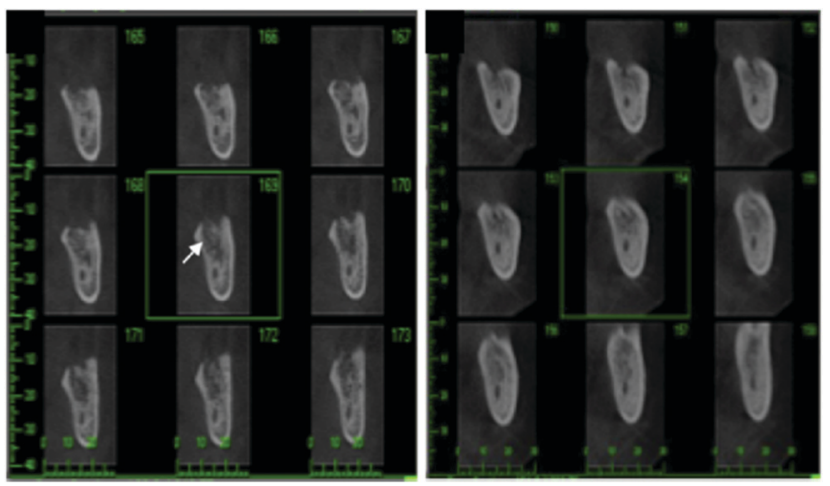

Fig. 4 Left: Initial cross-sectional CBCT images showed rarefaction of trabecular bone with a large area of osteonecrotic lesion around the extraction socket (as indicated by the white arrow). Right: After 2 years of SR treatment, CBCT images demonstrated that the bone density increased, and new spongy bone had begun to fill into the area previously occupied by dead bone. Reproduced under a Creative Commons Attribution - Non Commercial (unported, v3.0) License from Clin. Interventions Aging 2017, 12, 1089-1093 with permission from Dove Medical Press ${ }^{\circledR}$. 
A

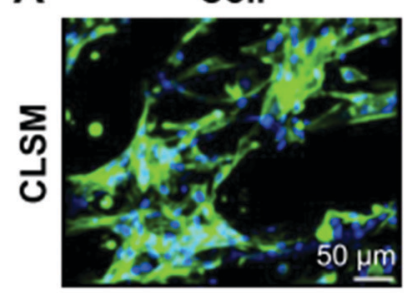

B

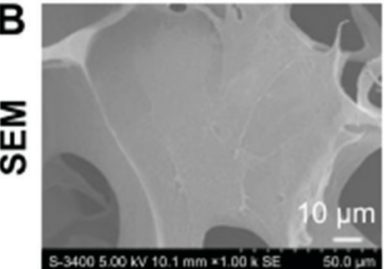

MHMs/Coll
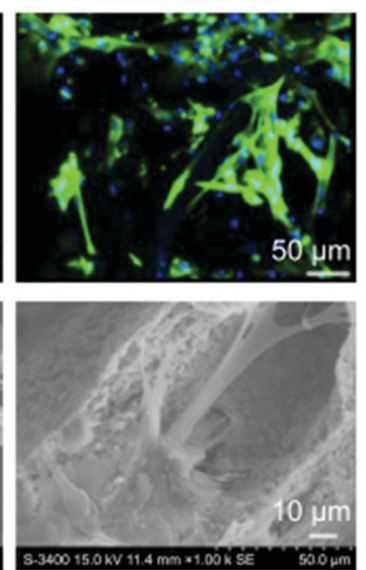

Zn2-MHMs/Coll
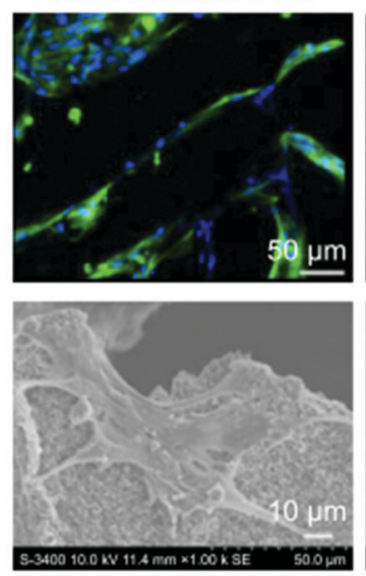

Zn5-MHMs/Coll
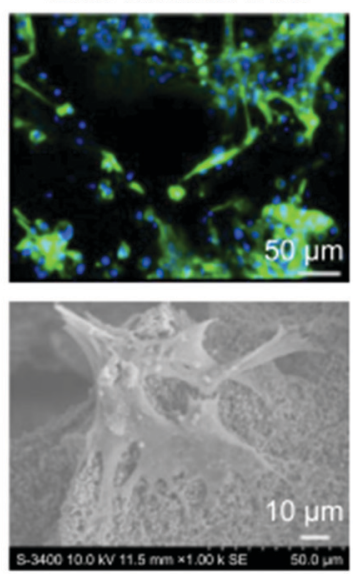

Fig. 5 Cell morphology observation and viability assay on the Coll, MHM/Coll, Zn2-MHM/Coll, and Zn5-MHM/Coll scaffolds. (A and B) CLSM and SEM images of rBMSCs on each type of scaffold after 7 days of culture. Reproduced under a Creative Commons Attribution - Non Commercial (unported, v3.0) License from International J. Nanomed. 2017, 12, 2293-2306 with permission from Dove Medical Press ${ }^{\mathbb{R}}$.

to calcium polyphosphate microparticles (Ca-a-polyP-MP) and $\beta$-tricalcium phosphate ( $\beta$-TCP), which were applied to Sarcoma Osteogenic cells (SAOS-2) and hMSC cells. These MPs were encapsulated in PGLA microspheres (MS), which leaves them with three samples to contrast: $\beta$-TCP-MS, Ca-a-polyP-MS ${ }^{99}$ and lastly, SR loaded PGLA microspheres (PM), where PGLA was degraded by hydrolysis into lactic and glycolic acid, which can develop into an inflammatory response. To this end, three samples were fabricated and contrasted: PM, SR-PM and SR-PM loaded with hydroxyapatite nanoparticles (SR-PM-HA), and MC3T3E1 cells were treated with them believing the microspheres with HA can neutralize the acidity of the lactic and glycolic acid. ${ }^{100}$

\section{Composite materials loaded with zinc and strontium}

As previously mentioned, $\mathrm{Zn}$ is crucial for growth and development. Although the pathways are not completely recognized, it has been shown that $\mathrm{Zn}$ has a protective effect on bone loss by enhancing bone formation and restraining bone resorption, having a therapeutic effect on bone disorders. ${ }^{101}$ Additionally, the use of electromagnetic fields (EMFs) has shown curative effects in osteoporosis treatments. ${ }^{102}$ Fathi E. et al. attempt to accomplish intensified osteogenic differentiation by exposing samples to EMF whilst treating with $\mathrm{ZnSO}_{4}$. The samples used were the control (neither $\mathrm{ZnSO}_{4}$ nor EMF exposure), EMF (without $\mathrm{ZnSO}_{4}$ yet $50 \mathrm{~Hz}, 20 \mathrm{mT}$ EMF exposure), $\mathrm{ZnSO}_{4}$ (without EMF exposure yet $0.432 \mu \mathrm{g} \mathrm{ml}^{-1} \mathrm{ZnSO}_{4}$ ) and lastly $\mathrm{EMF}+\mathrm{ZnSO}_{4}$ $\left(0.432 \mu \mathrm{g} \mathrm{ml}^{-1} \mathrm{ZnSO}_{4}\right.$ and $50 \mathrm{~Hz}, 20 \mathrm{mT}$ EMF exposure) and they were applied to ADSC cells. ${ }^{103}$

The potential characteristics in osteoinduction of zinc silicate have been studied using different methods. One uses a reduced graphene oxide/zinc silicate/calcium silicate (RGO/ZS/CS) electroconductive biocomposite by spin-coating zinc silicate and strontium alginate (SA) onto a calcium silicate disk (ZS/CS disk), while simultaneously reducing graphite into reduced graphene oxide (RGO) and creating an RGO/SA suspension. Once everything was prepared, RGO/SA was spin coated onto $\mathrm{ZN} / \mathrm{CS}$ disks and annealed at several temperatures, achieving $\mathrm{RGO} / \mathrm{ZN} / \mathrm{CS}$ biocomposites, which were further applied to BMSC cells. ${ }^{104}$ Another uses willemite $\left(\mathrm{ZnSiO}_{4}\right)$ coated polymeric fibrous polyethersulphone-polyethylene glycol (PES-PEG) bioceramic nanoparticles. The PEG-PES fibers were fabricated by electrospinning followed by the immersion of the fibers into a $1 \mathrm{wt}(\%)$ $\mathrm{Zn}_{2} \mathrm{SO}_{4}$ solution and they were used to treat SAOS and hMSC cells. ${ }^{105}$

Additionally, particular methods were carried out in four of the analysed studies: Sr doped octacalcium phosphate (OCP) since it has been suggested that OCP is a precursor to biological apatite crystals, ${ }^{106}$ where several concentrations of $\mathrm{Sr}$ were prepared (1Sr-OCP, 5Sr-OCP, 10Sr-OCP, 15Sr-OCP, 25Sr-OCP) by introducing $\mathrm{Sr}$ into OCP by substitution of $\mathrm{Ca}^{2+}$ and testing whether there was an induction of osteogenic gene expression in BMSCs; ${ }^{107} \mathrm{Sr}$ doped hydroxyapatite membranes ( $\mathrm{SrHA}$ ), analysing three different samples: collagen membrane, Sr10 $\left(10 \mathrm{mg} \mathrm{ml}^{-1}\right)$ and $\operatorname{Sr} 20\left(20 \mathrm{mg} \mathrm{ml}^{-1}\right)$ with BMSCs and further along implanted into Wistar rats; ${ }^{108}$ a $\beta$-glycerophosphate ( $\beta$-GP) based gel known for its thermo-inducing gelation method, where three samples were compared: control (CS/G/ $\beta$-GP), Sr doped $(\mathrm{CS} / \mathrm{G} / \beta-\mathrm{GP} / \mathrm{Sr})$ and tricalcium phosphate doped $(\mathrm{CS} / \mathrm{G} / \beta-\mathrm{GP} /$ $\mathrm{TC}$ ), believing it would induce osteoblast differentiation from stem cells extracted from human exfoliated deciduous teeth (SHEDs) ${ }^{109}$ pure Sr folate salts obtained from folic acid and strontium chloride solutions comparing the results with calcium folate and folic acid in HOBs cells. ${ }^{110}$ The effects of pure $\mathrm{Zn}$ (99.9998\%) and $\mathrm{Mg}$ alloy ALZ31 (Mg96/Al3/Zn1) rods were evaluated $^{111}$ and so was the direct supplementation of SW1353 chondrosarcoma cells; ${ }^{112}$ the effect of strontium citrate was analysed on bone consolidation during mandibular distraction in New Zealand white rabbits; ${ }^{113}$ and ultimately, an injectable Sr 


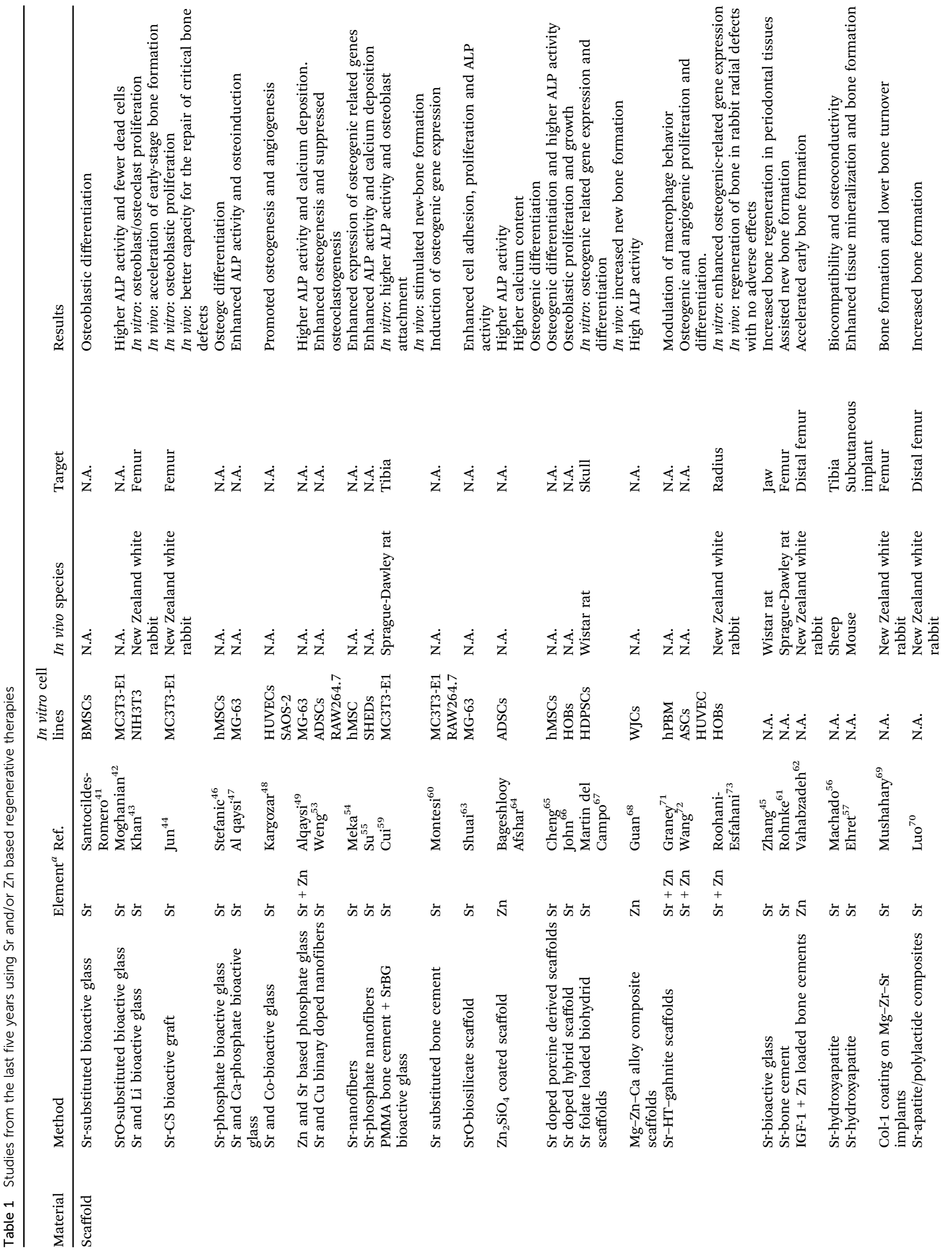


$\sum_{\substack{0 \\ \hline}}^{3}$

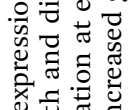

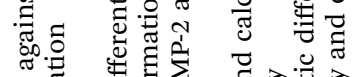

बि

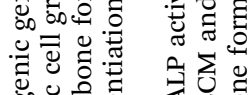

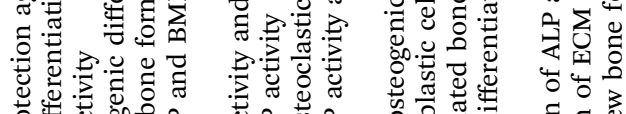

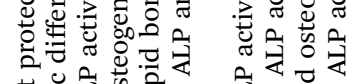

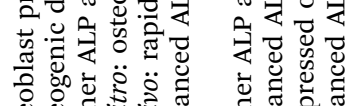

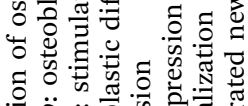

苞苛

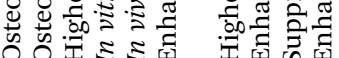

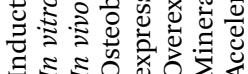

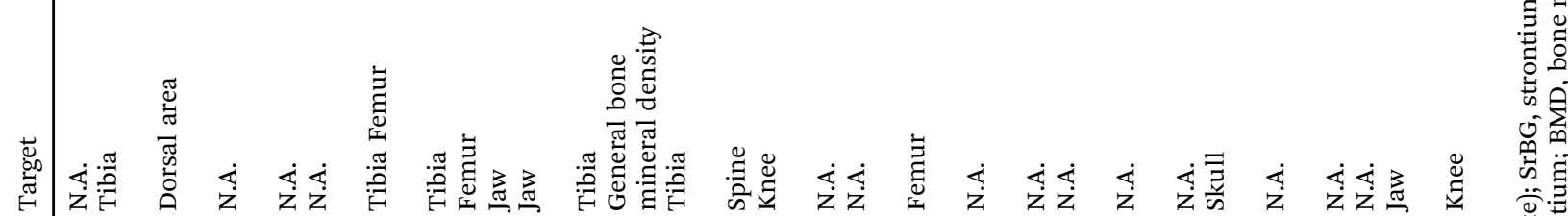

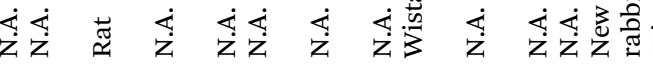

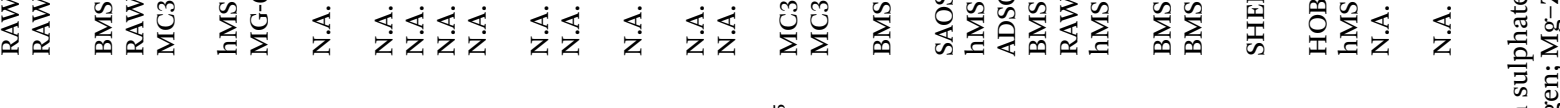

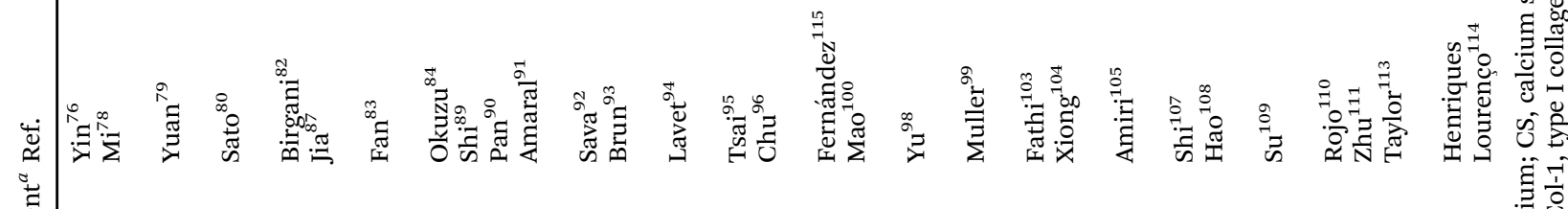

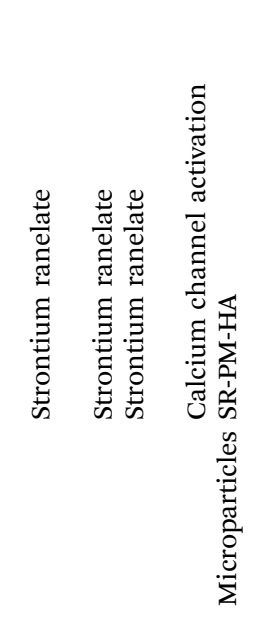

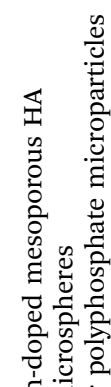

ลี สิ

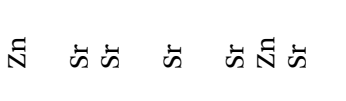

: 
hybrid system composed of a RGD-alginate hydrogel cross-linked with $\mathrm{Sr}$ and reinforced with $\mathrm{Sr}$ doped hydroxyapatite microspheres was investigated in Wistar Han rats. ${ }^{114}$

\section{Discussion and future perspectives}

Throughout the article, the latest advances in strontium and zinc based regenerative therapies have been reviewed. These two cations have attracted the attention of several research groups due to their safety, easy accessibility and high stability conferring regenerative characteristics to biomaterials. Sixtyeight articles which performed an investigation using $\mathrm{Sr}$ and/or $\mathrm{Zn}$ regenerative therapies were analysed, within which a great variety of in vitro and in vivo studies have been conducted in order to test new therapies and bone osteogenic strategies. As shown in Fig. S1 (ESI + ), these papers were organized into five main groups according to the biomaterial that was used in each study. The studies performed in vitro were roughly composed of half performed on animal cell lines, and the other half on human cell lines. Most of them analysed bone formation by evaluating: cell morphology and proliferation; differentiation into osteoblasts; expression of osteoblastic-related genes such as: alkaline phosphatase (ALP), runt-related transcription factor 2 (Runx2), osteocalcin (Bglap), collagen type I $\alpha$-chain (COL1), osteopontin (Spp1) and bone morphogenetic protein 2 (BMP2) by carrying out a PCR; and Ca deposition in the ECM. The inhibition of bone resorption was analysed by: inhibition of osteoclast formation (osteoclastogenesis) and inhibition of differentiation into osteoclasts.

On the other hand, the studies performed in vivo were composed of only two papers performing an in vivo human study. Amongst the twenty-seven articles found, eleven carried out the experiment on rats; nine utilized rabbits; three used mice; one used a guinea pig and lastly, another one worked with a sheep. The majority concluded with promising results by analysing: bone repair, new and/or increased bone formation, biocompatibility, osteoconductivity, reduced risk of fracture and augmented tissue mineralization. In addition, most of the studies analysed the effect of $\mathrm{Sr}$ and/or $\mathrm{Zn}$ in femur or tibia areas in animals. Furthermore, excepting three articles in which two used $\mathrm{Zn}$ and the other one combined $\mathrm{Sr}$ and $\mathrm{Zn}$; twenty-four of the studies performed in vivo used $\mathrm{Sr}$ as the main element to promote bone regeneration in osteoporotic - mostly induced - animal models. All these studies are summarized in Table 1 which helps to easily identify the method applied, element evaluated, tissues/cells targeted, and main results achieved from each study.

As the results showed for the in vitro studies, it is evident that $\mathrm{Sr}$ and $\mathrm{Zn}$ can not only induce osteogenesis and inhibit osteoclast formation, but also promote various processes such as calcification of the bone matrix and enhance osteogenicrelated genes that contribute to bone healing. The majority of the materials analysed resulted in bone formation or inhibition of bone resorption, obtaining as results: induction/enhancement of ALP activity of osteogenic related genes; osteoblastic differentiation or proliferation e.g. osteogenesis, angiogenesis, bone formation and osteoblastic formation among others; calcium deposition or mineralization of the ECM was also evaluated; inhibition of osteoclast formation or bone resorption; osteoblast attachment or enhanced cell adhesion; modulation of macrophage response or immunomodulation; and osteoblast protection against AGE.

A few drawbacks have been identified concerning vehiculation of divalent cations into biomaterials. Current evidence affirms that strontium ranelate mediates an uncoupling in bone turnover since it enhances osteogenesis and osteoblast activity while decreasing osteoclast differentiation and function; ${ }^{116}$ but also that it has serious side effects such as memory loss or increased risk of venous thromboembolism. ${ }^{15}$ However, new investigations substituting ranelic acid for vitamin-B derivatives of $\mathrm{Sr}$ or $\mathrm{Zn}$ are being recently described with very promising characteristics. ${ }^{117}$

Biocompatibility is crucial in terms of regenerative therapies; most of the studies were carried out using Zn and/or Sr doped scaffolds (bioactive glasses, nanofibers...), Ti surfaces and $\mathrm{Zn}$ compounds, which appear to have exceptional biocompatibility. $\mathrm{A} \mathrm{Sr}$ and $\mathrm{Zn}$ co-doped scaffold even achieved modulation of macrophage behaviour, ${ }^{71}$ implying no rejection from the cells. The $\mathrm{Sr}$ and/or $\mathrm{Zn}$ doped or loaded materials were able to stimulate a specific cellular response, thus exhibiting promising features to assist new bone formation, particularly relevant in the case of bone defects due to metabolic diseases, such as osteoporosis. Nonetheless, the weakness of the in vitro studies is that the data is complex to extrapolate due to the differences in the metabolism and drug development in distinct species and the different conditions of the surroundings when working in vivo.

On the other hand, the results from the in vivo studies also confirm that the addition of $\mathrm{Sr}$ and/or $\mathrm{Zn}$ can alter the physicomechanical characteristics and effectively enhance early stage in vivo osseointegration and recovery from bone turnover as well as tissue mineralization. The majority of the papers evaluated acceleration of early-stage bone formation/increased bone regeneration, yet some other results were pursued: recovery from bone resorption/turnover; augmented bone mass density (BMD); biocompatibility and osteoconductivity; enhanced tissue mineralization; decreased fracture incidence; early bone bonding, and prevented bone loss.

It should be noted that the one $\mathrm{Sr}$ and $\mathrm{Zn}$ co-doped scaffold concluded with the regeneration of bone in rabbit radial defects with no adverse effects. ${ }^{73}$ Most of the biomaterials used demonstrated proper setting times and high mechanical strength, and released ion products (such as $\mathrm{Ca}, \mathrm{Sr}, \mathrm{Zn}$ and P), imparting bioactivity to the composite cement and confirming the cytocompatibility of the composites. Nevertheless, only two studies were performed in humans, thus the same problem is faced: differences in the metabolism and drug development in distinct species. Moreover, the experiments taking place in humans were performed with SR which is already being used as an antiosteoporotic treatment, meaning that the novel and innovative proposals of regenerative therapies are yet to be tested in humans.

The obtained results of the in vitro cell culture and the in vivo studies suggest that $\mathrm{Sr}$ and/or $\mathrm{Zn}$ have the potential to address the unmet need for bone substitutes that can be used 
in load and partial load-bearing sites in orthopedic applications as well as in osteoporotic defects, inducing bone formation to a level comparable to healthy animals at an ectopic site. In addition, the cellular mechanisms by which $\mathrm{Sr}$ and $\mathrm{Zn}$ induce osteogenesis and inhibit osteoclastogenesis are mediated through the RANKL/RANK system by suppressing RANKL-stimulation in osteoclastogenesis. From the results of the aforesaid studies, it can also be deduced that the osteogenic-induced effect carried out by the addition of $\mathrm{Sr}$ and/or $\mathrm{Zn}$ is dose-dependent, meaning that lower doses than the established may not be able to provide the desired effects and higher doses can have detrimental effects.

The role of $\mathrm{Zn}$ in cartilage protection promoting healthy collagen II production and conformation has been proven. ${ }^{36}$ In addition, some authors have demonstrated that zinc can protect against the action of pro-inflammatory cytokines $(1 \mathrm{~L}-1 \beta)$ through the activation of antioxidant genes preventing osteoarthritis. Controversially, elevated $\mathrm{Zn}$ levels lead to the activation of biochemical pathways in chondrocytes that result in catabolic function in chondrocytes upregulating the matrix metalloproteinases enzymes, thus demonstrating anti-inflammatory effects of $\mathrm{Zn}$ sequestrating regenerative approaches. ${ }^{118}$ From the results of the aforesaid studies, it can also be deduced that the osteogenic-induced effect carried out by the addition of both $\mathrm{Sr}$ and/or $\mathrm{Zn}$ is dose-dependent, meaning that lower doses than the established may not be able to provide the desired effects and higher doses can have detrimental effects.

In conclusion, current investigations demonstrate that strontium and zinc induce human stem cell differentiation towards cartilage and bone like phenotypes in vitro and biomaterials containing such enhanced their performance both in vitro and in vivo, inducing new bone and cartilage tissue formation and inhibiting tissue resorption. Thus, novel organic and inorganic bioactive derivatives of strontium and zinc are in continuous development in order to overcome some limitations related to existing drugs and delivery systems. These compounds, together with new insights about the use of strontium and zincbased biomaterials, confirm their potential to inspire advanced tissue engineering therapies for emerging regenerative medicine.

\section{Conflicts of interest}

There are no conflicts to declare.

\section{Acknowledgements}

This work was supported by the Spanish Program MICINN (MAT201573656-JIN)

\section{References}

1 R. Florencio-Silva, G. Sasso, E. Sasso-Cerri, M. J. Simões and P. S. Cerri, BioMed Res. Int., 2015, 2015, 1-17.

2 G. A. Rodan and T. J. Martin, Science, 2000, 289, 1508-1514.

3 A. D. Woolf and B. Pfleger, Bull. W. H. O., 2003, 81, 646-656.
4 http://appsso.eurostat.ec.europa.eu/nui/submitViewTable Action.do.

5 A. S. Mao and D. J. Mooney, Proc. Natl. Acad. Sci. U. S. A., 2015, 112, 14452-14459.

6 P. V. Giannoudis, G. M. Calori, T. Bégué and G. Schmidmaier, Injury, 2015, 46, S1-S2.

7 https://www.iofbonehealth.org/what-is-osteoporosis.com.

8 N. Neves, D. Linhares, G. Costa, C. C. Ribeiro and M. A. Barbosa, Bone Jt. Res., 2017, 6, 366-375.

9 S. L. Teitelbaum, Science, 2000, 289, 1504-1508.

10 U.S. Department of Health and Human Services, Bone Health and Osteoporosis: A Report of the Surgeon General, U.S. Department of Health and Human Services, Office of the Surgeon General, Rockville, MD, 2004.

11 A. I. Gogakos, M. S. Cheung, J. H. D. Bassett and G. R. Williams, Expert Rev. Endocrinol. Metab., 2009, 4, 639-650.

12 S. C. Manolagas, Maturitas, 2014, 78, 233-237.

13 J. Kim and N. Kim, Chonnam Med. J., 2016, 52, 12-17.

14 Q. Bian, Y.-J. Wang, S. Liu and Y.-P. Li, Biochemistry, 2012, 1, 639-650.

15 C. McGreevy and D. Williams, Ther. Adv. Drug Saf., 2011, 2, 159-172.

16 C. Mason and P. Dunnill, Regener. Med., 2008, 3, 1-5.

17 Y. Tabata, J. R. Soc., Interface, 2009, 6, S311-S324.

18 F. Colombo, G. Sampogna, G. Cocozza, S. Y. Guraya and A. Forgione, J. Microsc. Ultrastruct., 2017, 5, 1-8.

19 G. Sampogna, S. Y. Guraya and A. Forgione, J. Microsc. Ultrastruct., 2015, 3, 101-107.

20 S. Pors Nielsen, Bone, 2004, 35, 583-588.

21 E. Abdullah, A. Idris and A. Saparon, ARPNJ. Eng. Appl. Sci., 2017, 12, 3218-3221.

22 J. M. Fernández, M. S. Molinuevo, A. D. McCarthy and A. M. Cortizo, Biometals, 2014, 27, 601-607.

23 W. Querido, A. L. Rossi and M. Farina, Micron, 2016, 80, 122-134.

24 S. Pasqualetti, G. Banfi and M. Mariotti, J. Trace Elem. Med. Biol., 2013, 27, 375-379.

25 G. M. Blake and I. Fogelman, Clin. Interv. Aging, 2006, 1, 367-375.

26 H. Y. Lee, D. Lie, K. S. Lim, T. Thirumoorthy and S. M. Pang, Osteoporos. Int., 2009, 20, 161-162.

27 A. Aimaiti, A. Maimaitiyiming, X. Boyong, K. Aji, C. Li and L. Cui, Stem Cell Res. Ther., 2017, 8, 282.

28 J. Zarins, M. Pilmane, E. Sidhom and I. Salma, Acta Chir. Latviensis, 2017, 17-23.

29 C. Cai, P. Lin, H. Zhu, J. K. Ko, M. Hwang, T. Tan, Z. Pan, I. Korichneva and J. Ma, J. Biol. Chem., 2015, 290, 13830-13839.

30 N. M. Lowe, W. D. Fraser and M. J. Jackson, Proc. Nutr. Soc., 2002, 61, 181-185.

31 J. Mayer, Postgrad. Med., 1964, 35, 206-209.

32 T. Fukada, S. Yamasaki, K. Nishida, M. Murakami and T. Hirano, J. Biol. Inorg. Chem., 2011, 16, 1123-1134.

33 C. R. Flannery, C. B. Little, C. E. Hughes and B. Caterson, Int. J. Exp. Pathol., 2000, 81, 1-29.

34 M. Demoor, D. Ollitrault, T. Gomez-Leduc, M. Bouyoucef, M. Hervieu, H. Fabre, J. Lafont, J. M. Denoix, F. Audigié, 
F. Mallein-Gerin, F. Legendre and P. Galera, Biochim. Biophys. Acta, Gen. Subj., 2014, 1840, 2414-2440.

35 L. Troeberg and H. Nagase, Biochim. Biophys. Acta, Proteins Proteomics, 2012, 1824, 133-145.

36 K. Rosenberg, H. Olsson, M. Morgelin and D. Heinegard, J. Biol. Chem., 1998, 273, 20397-20403.

37 A. Rahmani Del Bakhshayesh, N. Annabi, R. Khalilov, A. Akbarzadeh, M. Samiei, E. Alizadeh, M. AlizadehGhodsi, S. Davaran and A. Montaseri, Artif. Cells, Nanomed. Biotechnol., 2017, 1-15.

38 L. Rojo del Olmo, Adv. Exp. Med. Biol., 2018, 1059, 301-313.

39 L. Rojo, S. Radley-Searle, M. Fernandez-Gutierrez, L. M. Rodriguez-Lorenzo, C. Abradelo, S. Deb and J. San Roman, J. Mater. Chem. B, 2015, 3, 2708-2713.

40 M. N. Rahaman, D. E. Day, B. Sonny Bal, Q. Fu, S. B. Jung, L. F. Bonewald and A. P. Tomsia, Acta Biomater., 2011, 7, 2355-2373.

41 M. E. Santocildes-Romero, A. Crawford, P. V. Hatton, R. L. Goodchild, I. M. Reaney and C. A. Miller, J. Tissue Eng. Regener. Med., 2015, 9, 619-631.

42 A. Moghanian, S. Firoozi and M. Tahriri, Ceram. Int., 2017, 43, 14880-14890.

43 P. K. Khan, A. Mahato, B. Kundu, S. K. Nandi, P. Mukherjee, S. Datta, S. Sarkar, J. Mukherjee, S. Nath, V. K. Balla and C. Mandal, Sci. Rep., 2016, 6, 32964.

44 W. Jun, W. Peng, J. Dianming, L. Hong, L. Cong, L. Xing, Q. Xiangyang, C. Yujiang and L. Ming, RSC Adv., 2017, 7, 54306-54312.

45 Y. Zhang, L. Wei, C. Wu and R. J. Miron, PLoS One, 2014, 9, 1-6.

46 M. Stefanic, M. Peroglio, A.-M. Stanciuc, G. C. Machado, I. Campbell, M. M. Kržmanc, M. Alini and X. Zhang, J. Eur. Ceram. Soc., 2018, 887-897.

47 M. Al Qaysi, N. J. Walters, F. Foroutan, G. J. Owens, H.-W. Kim, R. Shah and J. C. Knowles, J. Biomater. Appl., 2015, 30, 300-310.

48 S. Kargozar, N. Lotfibakhshaiesh, J. Ai, M. Mozafari, P. Brouki Milan, S. Hamzehlou, M. Barati, F. Baino, R. G. Hill and M. T. Joghataei, Acta Biomater., 2017, 58, 502-514.

49 M. Alqaysi, A. Aldaadaa, N. Mordan, R. Shah and J. C. Knowles, Biomed. Mater., 2017, 12, 65011.

50 G. Kaur, G. Pickrell, N. Sriranganathan, V. Kumar and D. Homa, J. Biomed. Mater. Res., Part B, 2016, 104, 1248-1275.

51 X. Feng, Curr. Chem. Biol., 2009, 3, 189-196.

52 J. M. Holzwarth and P. X. Ma, Biomaterials, 2011, 32, 9622-9629.

53 L. Weng, S. K. Boda, M. J. Teusink, F. D. Shuler, X. Li and J. Xie, ACS Appl. Mater. Interfaces, 2017, 9, 24484-24496.

54 S. R. K. Meka, S. Jain and K. Chatterjee, Colloids Surf., B, 2016, 146, 649-656.

55 W. Su, P. Wu and T. Huang, Mater. Sci. Eng., C, 2015, 46, 427-434.

56 C. P. G. Machado, S. C. Sartoretto, A. T. N. N. Alves, I. B. C. Lima, A. M. Rossi, J. M. Granjeiro and M. D. Calasans-Maia, Braz. Oral Res., 2016, 30, 1-11.

57 C. Ehret, R. Aid-Launais, T. Sagardoy, R. Siadous, R. Bareille, S. Rey, S. Pechev, L. Etienne, J. Kalisky, E. De
Mones, D. Letourneur and J. A. Vilamitjana, PLoS One, 2017, 12, 1-21.

58 L. Rojo, B. Vazquez, S. Deb and J. San Román, Acta Biomater., 2009, 5, 1616-1625.

59 X. Cui, C. Huang, M. Zhang, C. Ruan, S. Peng, L. Li, W. Liu, T. Wang, B. Li, W. Huang, M. N. Rahaman, W. W. Lu and H. Pan, J. R. Soc., Interface, 2017, 14, 20161057.

60 M. Montesi, S. Panseri, M. Dapporto, A. Tampieri and S. Sprio, PLoS One, 2017, 12, 1-13.

61 M. Rohnke, S. Pfitzenreuter, B. Mogwitz, A. Henß, J. Thomas, D. Bieberstein, T. Gemming, S. K. Otto, S. Ray, M. Schumacher, M. Gelinsky and V. Alt, J. Controlled Release, 2017, 262, 159-169.

62 S. Vahabzadeh, A. Bandyopadhyay, S. Bose, R. Mandal and S. K. Nandi, Integr. Biol., 2015, 7, 1561-1573.

63 C. Shuai, H. Sun, P. Wu, C. Gao, Y. Yang, W. Guo, D. Yang, F. Xu, P. Feng and S. Peng, RSC Adv., 2017, 7, 21749-21757.

64 B. Bageshlooyafshar, S. Vakilian, M. Kehtari, T. EslamiArshaghi, F. Rafeie, R. Ramezanifard, R. Rahchamani, A. Mohammadi-Sangcheshmeh, Y. Mostafaloo and E. Seyedjafari, Res. Vet. Sci., 2017, DOI: 10.1016/j.rvsc. 2017.09.015.

65 A. D. Cheng, Q. Liang and Y. Li, Colloids Surf., B, 2018, 162, 279-287.

66 Ł. John, M. Podg, J. Nedelec, Ł. Cwynar and P. Dzięgiel, Mater. Sci. Eng., C, 2016, 68, 117-127.

67 M. Martin-del-Campo, R. Rosales-Ibañez, K. Alvarado, J. G. Sampedro, C. A. Garcia-Sepulveda, S. Deb, J. San Román and L. Rojo, Biomater. Sci., 2016, 4, 1596-1604.

68 F. Guan, S. Ma, X. Shi, X. Ma, L. Chi, S. Liang, Y. Cui, Z. Wang, N. Yao, S. Guan and B. Yang, Sci. China: Life Sci., 2014, 57, 181-187.

69 D. Mushahary, C. Wen, J. M. Kumar, R. Sravanthi, P. Hodgson, G. Pande and Y. Li, Clin. Oral. Implants Res., 2016, 27, e15-e24.

70 X. Luo, D. Barbieri, R. Duan, H. Yuan and J. D. Bruijn, Acta Biomater., 2015, 26, 331-337.

71 P. L. Graney, S.-I. Roohani-Esfahani, H. Zreiqat and K. L. Spiller, J. R. Soc., Interface, 2016, 13, 20160346.

72 G. Wang, S.-I. Roohani-Esfahani, W. Zhang, K. Lv, G. Yang, X. Ding, D. Zou, D. Cui, H. Zreiqat and X. Jiang, Sci. Rep., 2017, 7, 41135.

73 S. I. Roohani-Esfahani, C. R. Dunstan, J. J. Li, Z. Lu, B. Davies, S. Pearce, J. Field, R. Williams and H. Zreiqat, Acta Biomater., 2013, 9, 7014-7024.

74 J. J. Li, M. Ebied, J. Xu and H. Zreiqat, Adv. Healthcare Mater., 2018, 7, 1701061.

75 D. Losic, M. S. Aw, A. Santos, K. Gulati and M. Bariana, Expert Opin. Drug Delivery, 2015, 12, 103-127.

76 L. Yin, J. Zhou, L. Gao, C. Zhao, J. Chen, X. Lu, J. Wang, J. Weng and B. Feng, Surf. Coat. Technol., 2017, 330, 121-130.

77 B. Palla-Rubio, N. Araújo-Gomes, M. Fernández-Gutiérrez, L. Rojo, J. Suay, M. Gurruchaga and I. Goñi, Carbohydr. Polym., 2019, 203, 331-341.

78 B. Mi, W. Xiong, N. Xu, H. Guan, Z. Fang, H. Liao, Y. Zhang, B. Gao, X. Xiao, J. Fu and F. Li, Sci. Rep., 2017, 7, 2328. 
79 X. Yuan, H. Cao, J. Wang, K. Tang, B. Li, Y. Zhao, M. Cheng, H. Qin, X. Liu and X. Zhang, Front. Immunol., 2017, 8, 1196.

80 M. Sato, P. Chen, Y. Tsutsumi, M. Shiota, T. Hanawa and S. Kasugai, Dent. Mater. J., 2016, 35, 627-634.

81 L. H. Li, H. W. Kim, S. H. Lee, Y. M. Kong and H. E. Kim, J. Biomed. Mater. Res., Part A, 2005, 73, 48-54.

82 Z. T. Birgani, A. Malhotra, C. A. van Blitterswijk and P. Habibovic, J. Biomed. Mater. Res., Part A, 2016, 104, 1946-1960.

83 Y. P. Fan, X. Y. Chen, Y. Chen, G. L. Yang, H. M. Wang and F. M. He, Clin. Oral. Implants Res., 2017, 28, 911-919.

84 Y. Okuzu, S. Fujibayashi, S. Yamaguchi, K. Yamamoto, T. Shimizu, T. Sono, K. Goto, B. Otsuki, T. Matsushita, T. Kokubo and S. Matsuda, Acta Biomater., 2017, 63, 383-392.

85 J. Venkatesan, R. Nithya, P. N. Sudha and S. K. Kim, Role of alginate in bone tissue engineering, Elsevier Inc., 1st edn, 2014, vol. 73.

86 E. S. Place, L. Rojo, E. Gentleman, J. P. Sardinha and M. M. Stevens, Tissue Eng., Part A, 2011, 17, 2713-2722.

87 N. Yuan, L. Jia, Z. Geng, R. Wang, Z. Li, X. Yang, Z. Cui, S. Zhu, Y. Liang and Y. Liu, BioMed Res. Int., 2017, 2017, 9867819.

88 S. Lam and K. Zouzias, Consult. Pharm., 2008, 330, 1400-1401. 89 C. Shi, B. Hu, L. Guo, P. Cao, Y. Tian, J. Ma, Y. Chen, H. Wu, J. Hu, L. Deng, Y. Zhang and W. Yuan, J. Bone Miner. Res., 2016, 31, 1003-1014.

90 W.-L. Pan, P.-L. Chen, C.-Y. Lin, Y.-C. Pan, Y.-R. Ju, C.-P. Chan and R. W. W. Hsu, Clin. Interventions Aging, 2017, 12, 1089-1093.

91 S. A. Amaral, I. D. G. Reis, P. A. D. Oliveira, F. O. Costa, A. M. de Goes, G. A. B. Silva and L. O. de M. Cota, Int. J. Clin. Exp. Med., 2017, 10, 10616-10624.

92 A. Nemtoi, V. Danila, E. Dragan, S. Paşca, A. Nemtoi, M. Constantin, A. Sava and D. Haba, Rev. Chim., 2017, 68, 693-697.

93 L. R. Brun, A. M. Galich, E. Vega, H. Salerni, L. Maffei, V. Premrou, P. R. Costanzo, M. A. Sarli, P. Rey, M. S. Larroudé, M. S. Moggia, M. L. Brance and A. Sánchez, SpringerPlus, 2014, 3, 676.

94 C. Lavet, G. Mabilleau, D. Chappard, R. Rizzoli and P. Ammann, Osteoporosis Int., 2017, 28, 3475-3487.

95 T. T. Tsai, C. L. Tai, N. Y. J. Ho, P. L. Lai, T. S. Fu, C. C. Niu, L. H. Chen and W. J. Chen, PLoS One, 2017, 12, 1-16.

96 J.-G. Chu, M.-W. Dai, Y. Wang, F.-M. Tian, H.-P. Song, Y.-P. Xiao, L.-T. Shao, Y.-Z. Zhang and L. Zhang, BMC Musculoskelet. Disord., 2017, 18, 78.
97 J. Hendriks, J. Riesle and C. A. van Blitterswijk, J. Tissue Eng. Regener. Med., 2010, 4, 524-531.

98 W. Yu, T. W. Sun, C. Qi, Z. Ding, H. Zhao, S. Zhao, Z. Shi, Y. J. Zhu, D. Chen and Y. He, Int. J. Nanomedicine, 2017, 12, 2293-2306.

99 W. E. G. Müller, E. Tolba, M. Ackermann, M. Neufurth, S. Wang, Q. Feng, H. C. Schröder and X. Wang, Acta Biomater., 2017, 50, 89-101.

100 Z. Mao, Z. Fang, Y. Yang, X. Chen, Y. Wang, J. Kang, X. Qu, W. Yuan and K. Dai, RSC Adv., 2017, 7, 24607-24615.

101 M. Yamaguchi, Biomed. Res. Trace Elem., 2004, 15, 9-14.

102 R. Wang, H. Wu, Y. Yang and M. Song, Electromagn. Biol. Med., 2016, 35, 384-390.

103 E. Fathi and R. Farahzadi, PLoS One, 2017, 12, 1-19.

104 K. Xiong, T. Wu, Q. Fan, L. Chen and M. Yan, ACS Appl. Mater. Interfaces, 2017, 9, 44356-44368.

105 B. Amiri, M. Ghollasi, M. Shahrousvand, M. Kamali and A. Salimi, Differentiation, 2016, 1-11.

106 O. Suzuki, H. Imaizumi, S. Kamakura and T. Katagiri, Curr. Med. Chem., 2008, 15, 305-313.

107 H. Shi, X. Ye, T. Wu, J. Zhang and J. Ye, Mater. Today Chem., 2017, 5, 81-91.

108 J. Hao, A. Acharya, K. Chen, J. Chou, S. Kasugai and N. P. Lang, Clin. Oral. Implants Res., 2015, 26, 1-7.

109 W. Su, W. Chou and C. Chou, Mater. Sci. Eng., C, 2015, 52, 46-53.

110 L. Rojo, S. Radley-Searle, M. Fernandez-Gutierrez, L. M. Rodriguez-Lorenzo, C. Abradelo, S. Deb and J. San Roman, J. Mater. Chem. B, 2015, 3, 2708-2713.

111 D. Zhu, Y. Su, M. L. Young, J. Ma, Y. Zheng and L. Tang, ACS Appl. Mater. Interfaces, 2017, 9, 27453-27461.

112 E. B. Fung, J. L. Kwiatkowski, J. N. Huang, G. Gildengorin, J. C. King and E. P. Vichinsky, Am. J. Clin. Nutr., 2013, 98, 960-971.

113 B. A. Taylor, M. Bezuhly, M. Brace, M. Carter and P. Hong, Laryngoscope, 2017, 127, E212-E218.

114 A. Henriques Lourenço, N. Neves, C. Ribeiro-Machado, S. R. Sousa, M. Lamghari, C. C. Barrias, A. Trigo Cabral, M. A. Barbosa and C. C. Ribeiro, Sci. Rep., 2017, 7, 5098.

115 J. M. Fernández, M. S. Molinuevo, C. Sedlinsky, L. Schurman, A. M. Cortizo and A. D. McCarthy, Eur. J. Pharmacol., 2013, 706, 41-47.

116 P. J. Marie, M. Hott, D. Modrowski, C. De Pollak, J. Guillemain, P. Deloffre and Y. Tsouderos, J. Bone Miner. Res., 1993, 8, 607-615.

117 D. Fernández-Villa, M. Jiménez Gómez-Lavín, C. Abradelo, J. San Román and L. Rojo, Int. J. Mol. Sci., 2018, 19, 4068.

118 P. Suárez, L. Rojo, Á. González-Gómez and J. S. Román, Macromol. Biosci., 2013, 13, 1174-1184. 